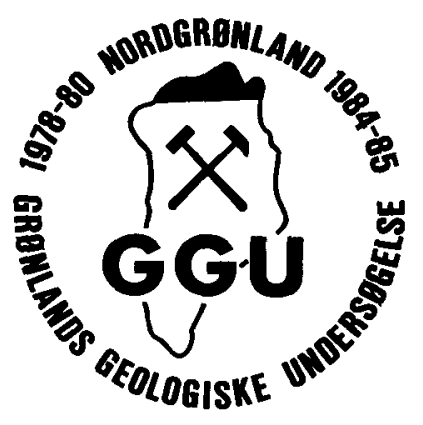

\title{
Preliminary analysis of the hydrocarbon source rock potential of central and western North Greenland
}

\author{
F. G. Christiansen, H. Nøhr-Hansen, \\ F. Rolle and P. Wrang
}

During the 1984 field season potential hydrocarbon source rocks were studied in central and western North Greenland. Samples from most lithostratigraphic units were collected from Freuchen Land in the north-east to Washington Land in the south-west. Preliminary results from LECO, Rock-Eval and palynofacies analyses suggest that some intervals in the Cambrian shelf sequence and in the Ordovician and Silurian trough sequence have enough organic matter to qualify as source rocks. Most of the trough sequence is, however, thermally postmature with respect to oil generation and only the Cambrian Brønlund Fjord Group is expected to have been the source of the oil accumulations in the subsurface.

F. G. C. \& H. N.-H., Grønlands Geologiske Undersøgelse, Øster Voldgade 10, DK-1350 Copenhagen K, Denmark.

F. R., BP Petroleum, Amaliegade 3, DK-1256 Copenhagen K, Denmark (formerly Grønlands Geologiske Undersøgelse).

P. W., Danmarks Geologiske Unders $\varnothing$ gelse, Thoravej $31, D K$ 2400 Copenhagen N.V., Denmark.

The aim of project 'Nordolie' (Christiansen \& Rolle, 1985) is to study the distribution and maturity of potential hydrocarbon source rocks in central and western North Greenland. Similar investigations have previously been undertaken to the east, in the Peary Land region and central North Greenland (Rolle, 1981; Rolle \& Wrang, 1981).

Field work was carried out by two geological teams from June to August 1984 as an integrated part of the survey mapping programme in the region. In 1985 the field work will concentrate on the most promising formations and areas and will involve drilling of slim-hole cores to depths of $\max .60 \mathrm{~m}$. The final selection of the drill sites and the areas for detailed studies depends on the preliminary analyses of maturity and source rock quality presented here.

This paper presents the results of the initial screening of the collected material by pyrolysis and optical studies of organic matter in the sediments. 


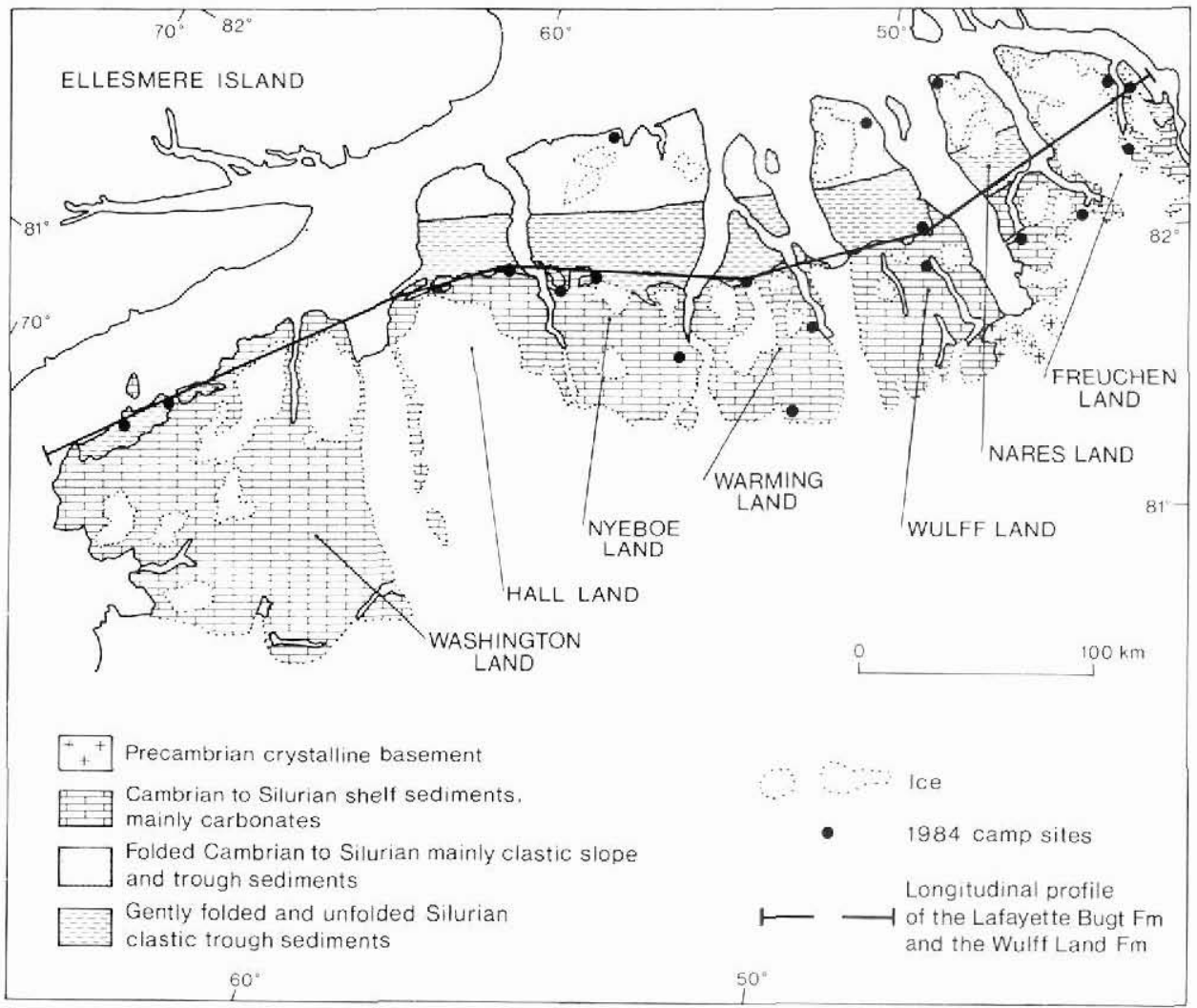

Fig. 1. Simplified geological map of central and western North Greenland showing camp sites and the position of the longitudinal profile (fig. 3). Based on Dawes (1976).

\section{Studied material}

600 samples were collected during the 1984 season covering the main part of the region (fig. 1). More than 200 of these were selected for initial laboratory analyses (Table 1). Special emphasis was placed on analysing a large number of shale samples from the Lafayette Bugt and Wulff Land Formations (Hurst, 1980; Hurst \& Surlyk, 1982) outcropping along the Silurian platform margin. A large number of dark dolomite and limestone samples from the Ordovician shelf sequence were also selected for analysis. The Cambrian limestones and shales, known to have a source potential in Peary Land, only outcrop in the eastern part of the studied area, from where a limited number of samples have been analysed. A smaller number of samples from most of the other formations have also been studied.

\section{Analytical methods}

The organic geochemical analyses have been carried out in the source rock laboratories of the Geological Survey of Denmark and the Geological Survey of Greenland. 
Table 1. Lithostratigraphic and regional distribution of samples analysed with LECO, Rock-Eval and optical methods

\begin{tabular}{|c|c|c|c|c|c|c|c|c|c|}
\hline & 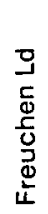 & 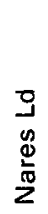 & $\frac{3}{3}$ & 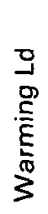 & 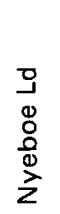 & $\begin{array}{l}\underline{D} \\
\overline{\bar{\pi}} \\
\frac{10}{I}\end{array}$ & 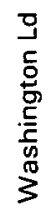 & 要 & \\
\hline $\begin{array}{l}\text { Pre-Portfjeld - Buen Fm } \\
\text { Brønlund Fjord Gp } \\
\text { Tavsens Iskappe Gp }\end{array}$ & $\begin{array}{l}5 \\
7 \\
5\end{array}$ & 4 & $\begin{array}{l}9 \\
- \\
-\end{array}$ & - & $\begin{array}{l}- \\
-\end{array}$ & - & $\begin{array}{l}- \\
-\end{array}$ & $\begin{array}{c}14 \\
11 \\
5\end{array}$ & \multirow[t]{2}{*}{41} \\
\hline Ryder Gletscher Gp & - & 1 & 4 & 6 & - & - & & 11 & \\
\hline $\begin{array}{l}\text { Wandel Valley Fm } \\
\text { Børglum River Fm }\end{array}$ & $\begin{array}{l}4 \\
4\end{array}$ & & - & - & - & - & - & $\begin{array}{l}4 \\
4\end{array}$ & \multirow{3}{*}{67} \\
\hline $\begin{array}{l}\text { Johansen Ld Fm, Warming Ld Fm } \\
\text { and Steensby Gletscher Fm }\end{array}$ & - & 2 & 3 & 4 & 1 & & - & 10 & \\
\hline $\begin{array}{l}\text { Nunatami Fm } \\
\text { Cape Webster Fm } \\
\text { Morris Bugt Gp }\end{array}$ & $\begin{array}{l}- \\
- \\
-\end{array}$ & $\overline{1}$ & $\begin{array}{l}- \\
1 \\
6\end{array}$ & 4 & $\begin{array}{l}- \\
10\end{array}$ & & $\begin{array}{c}5 \\
4 \\
18\end{array}$ & $\begin{array}{c}5 \\
6 \\
38\end{array}$ & \\
\hline Washington Land Gp & 1 & 2 & 2 & & 7 & & 1 & 13 & 13 \\
\hline Polkorridoren Gp & & & - & - & 2 & - & - & 2 & 2 \\
\hline $\begin{array}{l}\text { Un-named Cambro-Ordovician } \\
\text { slope sequence }\end{array}$ & 7 & 4 & 2 & - & 3 & - & - & 16 & 16 \\
\hline $\begin{array}{l}\text { Lafayette Bugt Fm } \\
\text { (incl. Cap Schuchert Fm) } \\
\text { Wulff Land Fm } \\
\text { Merqujôq Fm and Lauge Koch } \\
\text { Land Fm }\end{array}$ & $\begin{array}{l}3 \\
4 \\
4\end{array}$ & 2 & $\begin{array}{c}18 \\
4 \\
2\end{array}$ & 9 & $\begin{array}{c}19 \\
4\end{array}$ & 9 & 9 & $\begin{array}{l}67 \\
14 \\
13\end{array}$ & 94 \\
\hline
\end{tabular}

The total carbon content (TC) and the total organic carbon content (TOC) of all samples were determined by combustion in a LECO IR 212 instrument before and after treatment with hot concentrated hydrochloric acid, respectively.

The Rock-Eval pyrolysis method (Espitalie et al., 1977; 1980; Tissot \& Welte, 1978; Horsfield et al., 1983; Tissot, 1984) was used to provide information on the source rock potential, type of organic matter and maturity of the samples. In this analysis the powdered samples are heated at a steadily increasing temperature from $300^{\circ} \mathrm{C}$ to $550^{\circ} \mathrm{C}$, and the hydrocarbon release curve typically shows two peaks. The first one, $\mathrm{S} 1$ at about $300^{\circ} \mathrm{C}$, is produced by hydrocarbons already present in the rock ( $\mathrm{mg} \mathrm{HC} / \mathrm{g}$ rock). The second, $\mathrm{S} 2$ between $410^{\circ} \mathrm{C}$ and $480^{\circ} \mathrm{C}$, correlates with hydrocarbons generated by thermal cracking of kerogen $(\mathrm{mg} \mathrm{HC} / \mathrm{g}$ rock). The $\mathrm{CO}_{2}$ generated during pyrolysis, in the temperature interval $300^{\circ} \mathrm{C}$ to $390^{\circ} \mathrm{C}$, is trapped and analysed by thermal conductivity detection as a third peak $\mathrm{S} 3$ ( $\mathrm{mg} \mathrm{CO}_{2} / \mathrm{g}$ rock). At increasing maturity the S1 peak gets larger at the expense of S2. Postmature samples show very small S2 peaks. Furthermore, the S2 peak moves towards higher temperature with 
Table 2. Correlation of the maturity parameters $R_{0}, T_{\max }$ and TAI used in the present study

\begin{tabular}{|c|c|c|c|c|c|c|c|c|}
\hline $\mathbf{R}_{0}:$ & \multicolumn{2}{|c|}{0.6} & \multicolumn{2}{|c|}{1.3} & \multicolumn{2}{|c|}{2.0} & \multicolumn{2}{|c|}{4.0} \\
\hline$T_{\max }$ & $410 \quad 4$ & 437 & \multicolumn{2}{|c|}{460} & \multicolumn{2}{|c|}{ - } & not defined & - \\
\hline TAI: 1 & $1+2-$ & 2 & $2+3-$ & 3 & $3+$ & $4-$ & $\begin{array}{ll}4 & 4+\end{array}$ & 5 \\
\hline \multicolumn{2}{|c|}{ immature } & \multicolumn{2}{|c|}{ mature } & \multicolumn{4}{|c|}{ postmature } & \\
\hline \multicolumn{2}{|c|}{ diagenesis } & & \multicolumn{3}{|c|}{ catagenesis } & \multicolumn{2}{|c|}{ metagenesis } & metamorphism \\
\hline
\end{tabular}

increasing maturity, and the temperature of maximum generation $\left(T_{\max }\right)$ can be applied as a measure of maturity. The mature zone corresponds to $T_{\max }$ values between $437^{\circ} \mathrm{C}$ and $460^{\circ} \mathrm{C}$, but variations due to different material types and mineral matrix have been observed (Espitalie et al., 1980; Evans et al., 1983; Katz, 1983). The values are, however, strongly dependent on the single laboratory procedure, and should be compared with other maturity parameters (Table 2).

Reservoir rocks containing migrated bitumen or residual tar often give quite large $\mathbf{S} 2$ values in addition to the expected S1 peaks (Clementz, 1979). These S2 peaks are distinguished from the ones generated from kerogen in source rocks by the skewness towards the S1 peak, and the often abnormal $T_{\max }$.

Optical studies were carried out on kerogen separated from each sample by palynological preparation, where the minerals are dissolved by $\mathrm{HCl}$ and $\mathrm{HF}$. The first palynological slide is made after this acid treatment. The second slide is made of organic residue which has been sieved in a $\mathbf{1 0}$ micron nylon mesh. Finally a third slide is made of organic residue, which has been oxidised with fuming $\mathrm{HNO}_{3}$. The colour of the amorphous or structured kerogen is evaluated using the Thermal Alteration Index (TAI) of Staplin (1969) and Burgess (1974) based on the first or second slide. With increasing colouration of the organic matter the TAI varies from 1 to 5. This range corresponds to an increase in organic metamorphism (Staplin, 1969). The 'oil window' or the mature zone is represented by TAI values of 2 to $3^{-}$(Table 2). The third slide is used to identify palynomorphs for stratigraphic purposes. So far spores, chitinozoans, acritarchs and scolecodonts have been reported.

\section{Analytical results}

\section{Cambrian shelf facies}

The sequence of shales, coarse sandstones and dark dolomites underlying the Portfjeld Formation in the northern part of the region is not yet recognised as a formal lithostratigraphic unit. It has only been studied in northern Wulff Land, where a section, more than $450 \mathrm{~m}$ thick, was sampled. The TOC values vary between $0.2 \%$ and $0.8 \%$ in the shales, which mainly occur in the lowest part, whereas the dolomites higher in the section have a TOC content of less than $0.2 \%$.

The pale dolomites with minor sandstones of the Portfjeld Formation (Jepsen, 1971; 
O'Connor, 1979) have only been cursorily studied in Freuchen Land and northern Wulff Land. No analytical work has been performed.

The overlying Buen Formation is dominated by sandstone in the lower part and by siltstone and shale in the upper part (Jepsen, 1971; Christie \& Peel, 1977). The shales are greenish and generally bioturbated, and analyses from the Peary Land region show very low contents of organic matter (Rolle \& Wrang, 1981). The sandstones in the lower part of the Buen Formation are potential reservoir rocks, and dark bitumen-impregnated sandstones have been reported from southern Wulff Land by A. Steenfelt and U. Jacobsen (personal communication, 1984). Two samples, collected at more than $10 \mathrm{~km}$ distance, show fairly high contents of migrated hydrocarbons which have been degraded to a tar-like material. Both samples are from the vicinity of a regional fault system where the Buen Formation is in tectonic contact with the overlying Ryder Gletscher Group.

Cambrian carbonates above the Buen Formation can be subdivided into two laterally equivalent sequences. The Brønlund Fjord and Tavsens Iskappe Groups occur in Peary Land and as far west as south-west Freuchen Land (Ineson \& Peel, 1980; in press), while the Ryder Gletscher Group occurs in more south-westerly outcrops, as far west as southern Wulff Land and Warming Land (Peel \& Wright, 1985).

The Brønlund Fjord Group contains the most promising source rock intervals in the shelf sequence. Especially the Henson Gletscher Formation (Peel, 1979; Ineson, 1980; Ineson \& Peel, 1980; in press) with interbedded dolomite, shale and limestone is interesting in Freuchen Land and Nares Land. The shaly intervals contain between 1 and $2.5 \%$ TOC, and the black carbonates show signs of migrated hydrocarbons. Similar promising results were obtained in samples from western Peary Land (Rolle \& Wrang, 1981). Neither the thickness of the shaly source rock intervals nor the lateral distribution of the Henson Gletscher Formation is known in detail. It disappears suddenly in south-west Freuchen Land (Peel \& Wright, 1985) but probably extends northwards into the postmature area around Navarana Fjord (A. K. Higgins \& J. S. Peel, personal communication, 1984).

None of the analysed samples from the Tavsens Iskappe Group are of source rock quality and the TOC values are lower than $0.2 \%$. Impressive bitumen-filled breccias in southern Freuchen Land suggest that considerable amounts of hydrocarbons have been generated, and that migration, possibly from the underlying Henson Gletscher Formation, has taken place. Of particular interest is the possible presence of stratigraphic traps under the regional sub-Wandel Valley Formation unconformity (Peel, 1979; Rolle \& Wrang, 1981).

All the analysed samples of the Ryder Gletscher Group are low in TOC (less than $0.2 \%$ ), but fractured carbonates and dark sandstones impregnated with bitumen are present in both southern Wulff Land and Warming Land, suggesting that some source rocks might be present.

Only few maturity data are reported from the Cambrian. South of Navarana Fjord the $T_{\max }$ is above $460^{\circ} \mathrm{C}$ and the TAI ranges from $3^{-}$to $3^{+}$. Further west the TAI decreases to 2 to $3^{-}$in southern Nares Land, and to 2 to $2^{+}$in southern Warming Land (fig. 2).

\section{Ordovician shelf facies}

A more than $1 \mathrm{~km}$ thick sequence of Ordovician shelf carbonates is exposed in an eastwest belt along the south margin of the land area in North Greenland. A large number of samples from these Ordovician sediments have been analysed. With few exceptions they all 


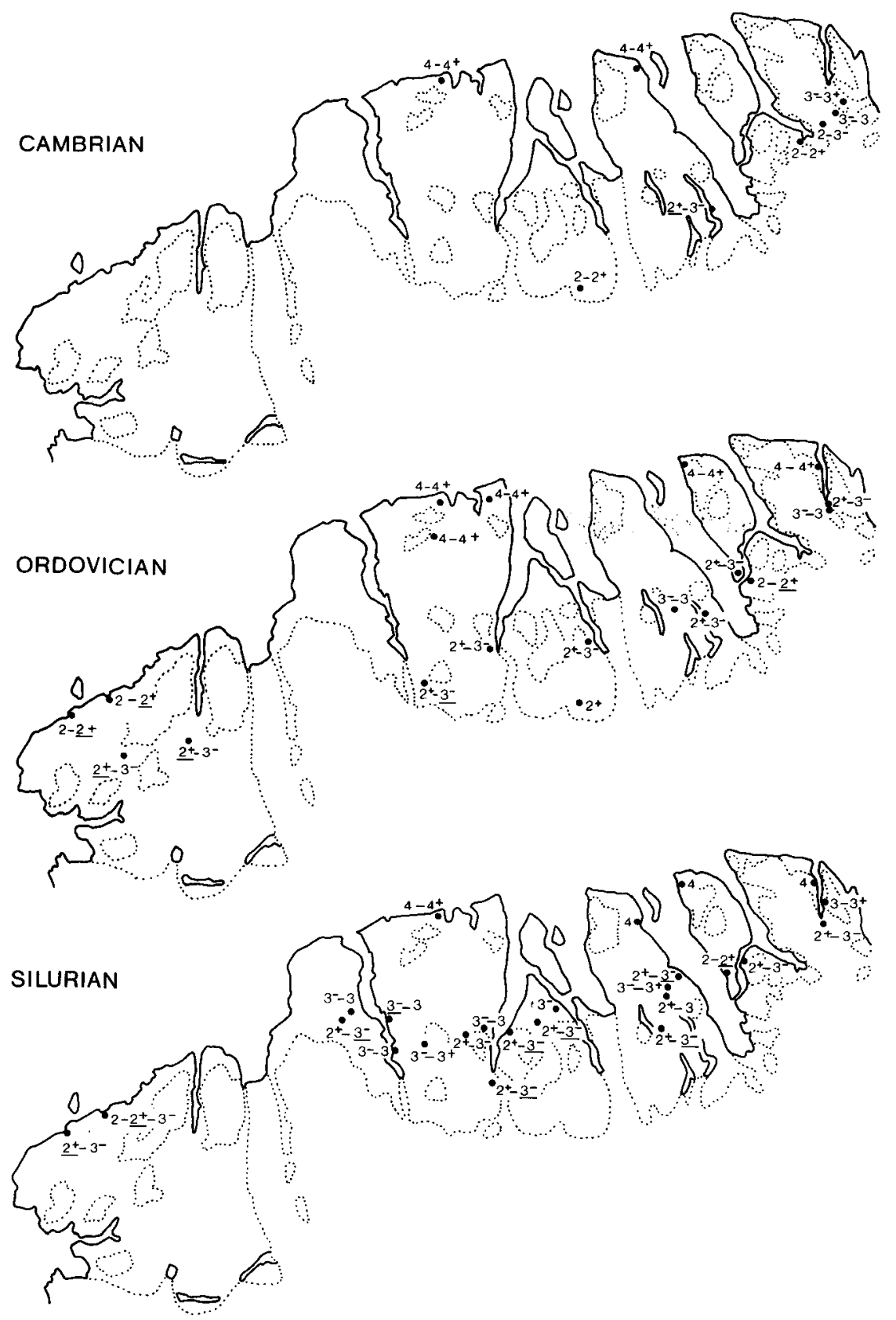

Fig. 2. Measured TAI (Thermal Alteration Index) values from the Cambrian, Ordovician and Silurian sequences. Map scale as in fig. 1. 
have less than $0.2 \%$ organic matter and are therefore without source potential. Four samples of shaly dolomite from the Cape Webster Formation in Washington Land (Sønderholm \& Due, 1985) have TOC values between $0.15 \%$ and $0.85 \%$. One sample from a thin shaly interval in the Aleqatsiaq Fjord Formation of the Morris Bugt Group (Peel \& Hurst, 1980) in Washington Land has more than $1 \%$ TOC. These samples, however, only represent very thin beds and do not influence the general source potential.

Due to the low content of organic matter it has only been possible to obtain geochemical information on maturity from two $T_{\max }$ values at $435^{\circ} \mathrm{C}$ and $438^{\circ} \mathrm{C}$, both from Washington Land. The TAI indicates favourable maturity of the Ordovician shelf sequence in southern Nares Land $\left(2-3^{-}\right)$and southern Warming Land $\left(2^{+}-3^{-}\right)$and slightly higher values in Wulff Land $\left(2^{+}-3\right)$ and Freuchen Land $\left(2^{+}-3\right)$ (fig. 2).

\section{Silurian shelf facies}

The Silurian Washington Land Group (Hurst, 1980) has only been cursorily examined because it forms the present erosion level. None of the analysed samples are of source rock quality (less than $0.1 \%$ TOC). No signs of migrated hydrocarbons have been detected, not even in samples in faulted contact to the Lafayette Bugt Formation.

\section{Cambro-Ordovician trough facies}

The Polkorridoren Group (Friderichsen et al., 1982) has only been sampled in northern Nyeboe Land where it occurs as greasy low metamorphic, reddish or greenish slates and psammites with a well developed slaty cleavage. The only two analysed samples have a TOC content of less than $0.2 \%$.

The shales, cherts and resedimented conglomerates which correspond to the Vølvedal and Amundsen Land Groups (Friderichsen et al., 1982) of the Peary Land region (= un-named Cambro-Ordovician slope sequence of Higgins \& Soper, 1985) only occur in the fold belt, and have been studied in the northern parts of Freuchen Land, Nares Land and Nyeboe Land. All three areas are thermally overmature with respect to hydrocarbon generation with TAI between $3^{+}$and $4^{+}$. Most of the samples have between $0.5 \%$ and $2 \%$ organic carbon, occasionally less than $0.1 \%$. The black graptolite shales, which are particularly abundant in the Freuchen Land section, contain more than 5\% TOC. These values indicate that some intervals of the Ordovician sequence were very good source rocks prior to subsidence and metamorphism. It is not likely, however, that the Ordovician shales occur with an appropriate maturity for oil generation anywhere in the studied region. However, a high gas potential may still be present in places.

\section{Silurian trough facies}

The Silurian margin between the shelf and the trough sequence is exposed with a total length of more than $400 \mathrm{~km}$ (fig. 1). The proximal part of the trough consists of the Cape Schuchert and Lafayette Bugt Formations (Hurst, 1980; Hurst \& Surlyk, 1982). The two formations have only been distinguished from each other in Washington Land, elsewhere they are considered together. They are characterised by laminated lime mudstones, shales, cal- 


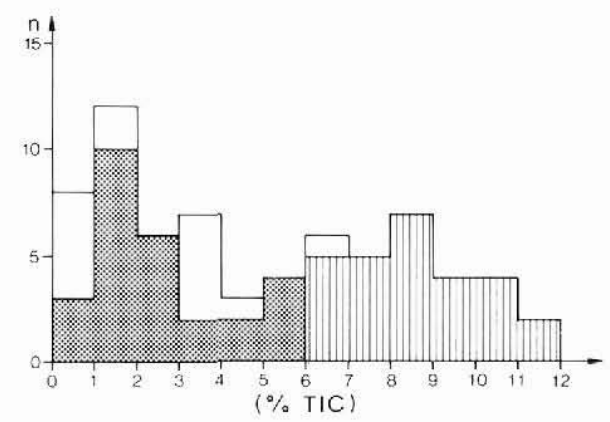

Fig. 3. Histogram of total inorganic carbon values (TIC) of the Lafayette Bugt Formation (shales are stippled; vertical hatching show lime mudstones) and the Wulff Land Formation (shown in white). Pure dolomite corresponds to c. $13 \%$ TIC, pure calcite to $12 \%$ TIC.

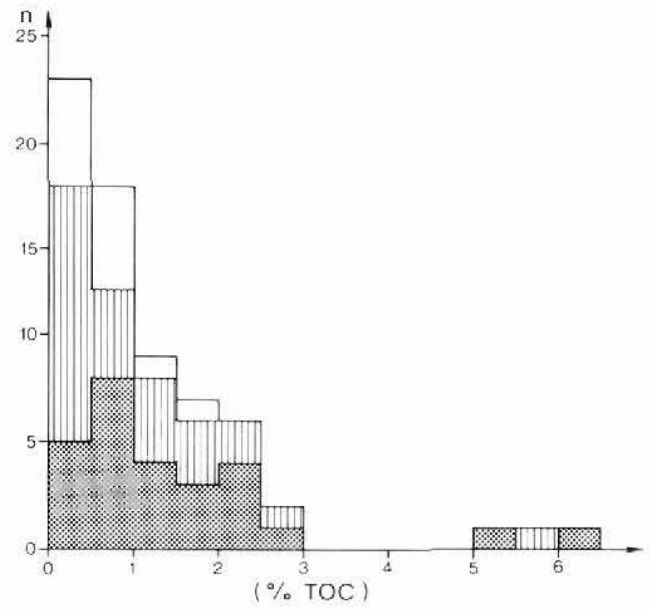

Fig. 4. Histogram of TOC (total organic carbon) analyses of the Lafayette Bugt Formation divided into shales with less than $6 \%$ TIC (stippled) and lime mudstones with more than $6 \%$ TIC (vertical hatching) and the Wulff Land Formation (in white).

carenites, conglomerates and impressive olistoliths up to hundreds of metres in size. Upwards and more distally the Lafayette Bugt Formation interdigitates with the Wulff Land Formation.

The fine grained sediments of the Lafayette Bugt Formation show a great range in TIC (total inorganic carbon) content with a tendency towards a bimodal distribution (fig. 3 ). The maximum values 1 to $2 \%$ TIC and 8 to $9 \%$ TIC correspond to modal carbonate contents of approximately 10 to $15 \%$ and 65 to $70 \%$, respectively. Many of the most carbonate-rich samples are from the reef associated facies in Hall Land and western Nyeboe Land. The Lafayette Bugt Formation is generally rich in organic matter. The carbonate-poor shales show a range from $0.5 \%$ to $2.5 \%$ TOC, whereas the carbonate-rich shales have a lower content (fig. 4). The interlayered stinking calcarenites and conglomerates have very low TOC values (less than $0.1 \%$ ) except for a few samples from Washington Land, where bitumen filled pores and fractures were observed in the field.

The siltstones of the Wulff Land Formation have a greater lateral extent than the shales and lime mudstones of the Lafayette Bugt Formation. The TIC content is usually less than $5 \%$ corresponding to approximately $40 \%$ modal carbonates (fig. 3 ). TOC values are typically around $0.5 \%$ (fig. 4), except for the Thors Fjord Member in Nares Land which has more than $2 \%$ TOC. Also the common thin layers of stinking calcarenites in the Wulff Land Formation have very low contents of organic carbon (typically less than $0.15 \%$ ), and no signs of migrated material have been found by pyrolysis.

Only a few scattered samples of the Merqujôq and Lauge Koch Land Formations (Hurst \& Surlyk, 1982) have been analysed. These are mainly from the thin silty to muddy layers in 


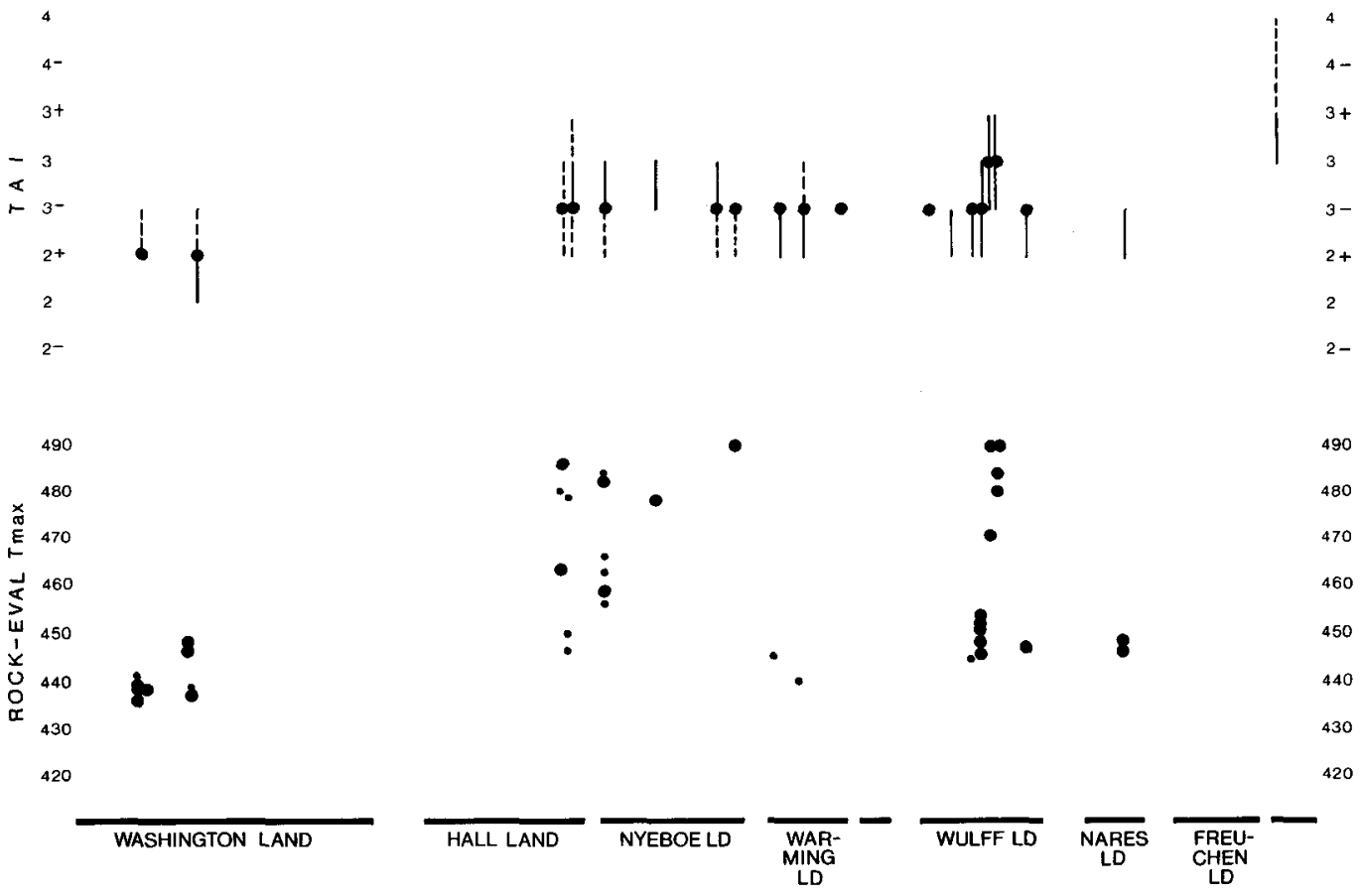

Fig. 5. Longitudinal profile showing the variation in maturity along the Silurian platform margin (Lafayette Bugt and Wulff Land Formations). $T_{\max }$ is shown as large dots (well defined values) or small dots (uncertain values). TAI is shown as dots (main values), lines (range), or as dashed lines (uncertain range).

the turbidites. The TOC content averages close to $0.2 \%$ with a variation between $0.1 \%$ and $0.5 \%$. The carbonate content is typically around $20 \%$.

The constantly high content of organic matter makes the Lafayette Bugt and Wulff Land Formations feasible targets in a regional maturity study. Fig. 5 shows the variation in maturity expressed by the two parameters TAI and $T_{\max }$ along the Silurian shelf margin from Freuchen Land in the north-east to Washington Land in the south-east. In eastern Freuchen Land the two formations are thermally overmature with TAI between 3 and 4, and $T_{\max }$ values are not recorded. From Nares Land to Warming Land the maturity seems rather constant. $T_{\max }$ values between $440^{\circ} \mathrm{C}$ and $450^{\circ} \mathrm{C}$ and TAI between $2^{+}$and $3^{-}$suggest a situation in the middle of the oil-window. Only the valley north of Apollo Sø in central Wulff Land has anomalously high maturity with TAI from $3^{-}$to $3^{+}$and $T_{\max }$ above $460^{\circ} \mathrm{C}$. Nyeboe Land and eastern Hall Land show high $T_{\max }$ values between $450^{\circ} \mathrm{C}$ and $480^{\circ} \mathrm{C}$, TAI from $2^{+}$to $3^{+}$, and are considered thermally postmature with respect to oil generation. The lowest maturity of the Lafayette Bugt Formation is recorded in Washington Land with $T_{\max }$ values between $436^{\circ} \mathrm{C}$ and $439^{\circ} \mathrm{C}$, and TAI down to 2 . This is in the oil window, close to the onset of oil generation, which is also confirmed by the common presence of migrated bitumen in the interbedded conglomerates. 


\section{Discussion}

All the analyses were carried out on surface samples. This creates problems in the interpretation, since weathering often seriously affects the content and composition of organic matter in sediments. The magnitude of this change is variable and depends on a number of factors such as mineralogy, porosity and permeability of the rock, type and thermal maturity of the organic matter as well as climate and biological activity in the exposed area.

Leythaeuser (1973) and Clayton \& Swetland (1978) report $25 \%$ and $60 \%$ less TOC, respectively, of surface samples versus deeper samples in the western USA. In a study from Svalbard, with a climate similar to North Greenland, Forsberg \& Bjorøy (1983) found an average loss of only $10 \%$ TOC in surface samples, whereas the amount of extractable organic matter and the relative amounts of aromatic versus saturated hydrocarbons are drastically lowered. It should also be kept in mind that a good source rock can produce oil corresponding to more than $60 \%$ of the initial TOC, so the original TOC content for the postmature samples has been significantly higher.

In the present study there seems to be good reproducibility of both LECO and Rock-Eval analyses with respect to lithostratigraphy and regional distribution. Thus the present screening methods are likely to produce a good preliminary indication of potential source rocks and an evaluation of the relative maturity of the region as a whole.

Analyses of drill-cores are expected to improve these data. Furthermore, fresh core samples will be necessary to obtain more reliable parameters on organic type and maturity from gas chromatography and mass spectrometry.

\section{Conclusion}

From the present screening it has become obvious that sediments with sufficient organic matter to qualify as source rocks for hydrocarbons are found in the Cambrian Brønlund Fjord Group, in the Ordovician graptolitic shales of the starved slope sequence, and in the Silurian Cape Schuchert, Lafayette Bugt, and Wulff Land Formations. Furthermore, the presence of an as yet unrecognised source rock within or below the Cambrian Ryder Gletscher Group may be predicted in order to explain the presence of bitumen in southern Wulff Land and Warming Land.

The thermal maturity pattern, which can be broadly defined on the basis of the analyses, shows that only the southern parts of Freuchen Land to Hall Land and probably most of Washington Land lie within the oil-window. Generally conditions corresponding to the end of the oil-window occurs at, or just north of, the exposed shelf/trough boundary. This implies that only the Cambrian shelf carbonates (Brønlund Fjord Group and equivalents) can be expected to have been the source of oil accumulations in the subsurface, whereas the more organic rich and thicker trough sediments can only have acted as the source for gas accumulations.

Acknowledgements. The project is supported by the Danish Ministry of Energy through project no. EFP 83-2251-305. A. T. Bruun and B. Sikker Hansen assisted with the preparation of the manuscript. 


\section{References}

Burgess,J. D. 1974: Microscopic examination of kerogen (dispersed organic matter) in petroleum exploration. Geol. Soc. Am., Spec. Pap. 153, 19-30.

Christiansen, F. G. \& Rolle, F. 1985: Project 'Nordolie': hydrocarbon source rock investigations in central North Greenland. Rapp. Gronlands geol. Unders. 125, 17-21.

Christie, R. L. \& Peel, J. S. 1977: Cambrian - Silurian stratigraphy of Børglum Elv, Peary Land, eastern North Greenland. Rapp. Grønlands geol. Unders. 82, 48 pp.

Clayton, J. L. \& Swetland, P. J. 1978: Subaerial weathering of sedimentary organic matter. Geochim. cosmochim. Acta 42, 305-312.

Clementz, D. M. 1979: Effect of oil and bitumen saturation on source rock pyrolysis. Bull. Am. Ass. Petrol. Geol. 63, 2227-2232.

Dawes, P. R. 1976: Precambrian to Tertiary of northern Greenland. In Escher, A. \& Watt, W. S. (edit.) Geology of Greenland, 248-303. Copenhagen: Geol. Surv. Greenland.

Espitalié, J., Laporte, J. L., Madec, M., Marquis, F., Leplat, P. 1977: Methode rapide de caracterisation des roches mères de leur potentiel pétrolier et de leur degré d'évolution. Revue Inst. fr. Pétrole 32, 23-42.

Espitalié, J., Madec, M. \& Tissot, B. 1980: Role of mineral matrix in kerogen pyrolysis: influence on petroleum generation and migration. Bull. Am. Ass. Petrol. Geol. 64, 59-66.

Evans, R. J. \& Felbeck Jr. G. T. 1983: High temperature simulation of petroleum formation - II. Effects of inorganic sedimentary constituents on hydrocarbon formation. Org. Geochem. 4, 145-152.

Forsberg, A. \& Bjorøy, M. 1983: A sedimentological and organic geochemical study of the Botneheia Formation, Svalbard, with special emphasis on the effects of weatering on the organic matter in shales. In Bjorøy, M. et al. (edit.) Advances in organic geochemistry, 1981, 60-68.

Friderichsen, J. D., Higgins, A. K., Hurst, J. M., Pedersen, S. A. S, Soper, N. J. \& Surlyk, F. 1982: Lithostratigraphic framework of the Upper Proterozoic and Lower Palaeozoic deep water clastic deposits of North Greenland. Rapp. Grønlands geol. Unders. 107, $19 \mathrm{pp}$.

Higgins, A. K. \& Soper, N. J. 1985: Cambrian - Lower Silurian slope and basin stratigraphy between northern Nyeboe Land and western Amundsen Land, North Greenland. Rapp. Grønlands geol. Unders. 126, 79-86.

Horsfield, B., Dembicki Jr. H. \& Ho, T. T. Y. 1983: Some potential applications of pyrolysis to basin studies. J. geol. Soc. London 140, 431-443.

Hurst, J. M. 1980: Silurian stratigraphy and facies distribution in Washington Land and western Hall Land, North Greenland. Bull. Grønlands geol. Unders. 138, 95 pp.

Hurst, J. M. \& Surlyk, F. 1982: Stratigraphy of the Silurian turbidite sequence of North Greenland. Bull. Grønlands geol. Unders. 145, 121 pp.

Ineson, J. R. 1980: Carbonate debris flows in the Cambrian of south-west Peary Land, eastern North Greenland. Rapp. Gronlands geol. Unders. 99, 43-49.

Ineson, J. R. \& Peel, J. S. 1980: Cambrian stratigraphy in Peary Land, eastern North Greenland. Rapp. Grønlands geol. Unders. 99, 33-42.

Ineson, J. R. \& Peel, J. S. in press: Cambrian shelf stratigraphy of the Peary Land region, central North Greenland. Bull. Grønlands geol. Unders.

Jepsen, H. F. 1971: The Precambrian, Eocambrian and early Palaeozoic stratigraphy of the Jørgen Brønlund Fjord area, Peary Land, North Greenland. Bull. Grønlands geol. Unders. 96, $42 \mathrm{pp}$.

Katz, B. J. 1983: Limitations of 'Rock-Eval' pyrolysis for typing organic matter. Org. Geochem. 4, 195199.

Leythaeuser, D. 1973: Effects of weathering on organic matter in shales. Geochim. cosmochim. Acta 37, 113-120.

O'Connor, B. 1979: The Portfjeld Formation (?early Cambrian) of eastern North Greenland. Rapp. Grønlands geol. Unders. 88, 23-28. 
Peel, J. S. 1979: Cambrian - Middle Ordovician stratigraphy of the Adams Gletscher region, south-west Peary Land, North Greenland. Rapp. Grønlands geol. Unders. 88, 29-39.

Peel, J. S. \& Hurst, J. M. 1980: Late Ordovician and early Silurian stratigraphy of Washington Land, western North Greenland. Rapp. Gronlands geol. Unders. 100, 18-24.

Peel, J. S. \& Wright, S. C. 1985: Cambrian platform stratigraphy in the Warming Land - Freuchen Land region, North Greenland. Rapp. Grønlands geol. Unders. 126, 17-24.

Rolle, F. 1981: Hydrocarbon source rock sampling in Peary Land 1980. Rapp. Grønlands geol. Unders. 106, 99-103.

Rolle, F. \& Wrang, P. 1981: En foreløbig oliegeologisk vurdering af Peary Land området i Nordgrønland. Unpubl. intern. rep., Grønlands geol. Unders., 21 pp.

Staplin, F. L. 1969: Sedimentary organic matter, organic metamorphism, and oil and gas occurrence. Bull. Can. Soc. Petrol. Geol. 17, 47-66.

Sønderholm, M. \& Due, P. H. 1985: Lower and Middle Ordovician platform carbonate lithostratigraphy of Warming Land, Wulff Land and Nares Land, North Greenland. Rapp. Grønlands geol. Unders. 126, 31-46.

Tissot, B. P. 1984: Recent advances in petroleum geochemistry applied to hydrocarbon exploration. Bull. Am. Ass. Petrol. Geol. 68, 545-563.

Tissot, B. P. \& Welte D. H. 1978: Petroleum formation and occurrence. Berlin, Heidelberg, New York: Springer Verlag. $538 \mathrm{pp}$. 